\begin{tabular}{|c|c|c|c|c|}
\hline DOI: 10.331 & ILHSS.74.20 & 1.616 & & $\begin{array}{l}\text { ISSN online: } 2414-3383 \\
\text { ISSN print: } 2616-3810 \\
\end{array}$ \\
\hline Ges & $\begin{array}{l}\text { glninlly } \\
\text { Journal of A }\end{array}$ & $\begin{array}{r}\text { s, Literature, Hum } \\
\text { www.jalhs }\end{array}$ & 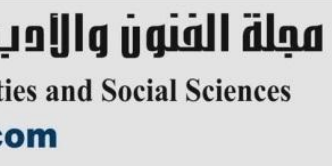 & \\
\hline$=$ & Volume (74) & December 2021 & العدد (74) ديسمبر 2021 & \\
\hline
\end{tabular}

\title{
The Historical and Heritage Richness of some Heritage Sites in Al-Baha Region
}

\author{
Dr. Laila bint Abd Alkarim Alzahrani \\ Assistant Professor - Department of History - Faculty of Arts and Humanities - Al-Baha \\ University - Saudi Arabia
}

\begin{abstract}
Al-Baha region is one of the main regions of Saudi Arabia. It is characterized by its historical and cultural legacy, as it combines many historical locations and remnants, which were and still bear witness the times experienced by the region. Tourists who visit the region can see its material history, through traces buried in some towns and in ancient cultural centers, and its superficial traces through its inscriptions and rock graphics, in addition to its villages, caves, cemeteries, weekly popular markets, dams and agricultural terraces and old routes. All these aspects deserve further studies and attention, which could attract large number of tourists if they revived and opened for tourism activity and providing infrastructure and facilities that serve this aspect. Due to unintended negligence, failure to pay attention to remnants or assigning the responsibility to non-qualified made the region lose an essential source of revenue. Based on the above, we hope to draw attention to carry out tourism development through (tourism revival) by developing the archeological sites for achieving full development with the aim of revitalizing the economic cycle and of encouraging the development of the region through sustainable development in a way that guarantees the revival of remnants and preservation of their authenticity. This study highlights the region itself such as surveying some of its sites and factors of their creation, showing some archeological sites, and reviewing tourism potential and the extent to which this potential is used for tourism purpose. Then, to identify the main troubles suffered by the visitors, and to propose the solutions with the aim of promoting and improving tourism service.
\end{abstract}

Keywords: Historical Richness, Heritage Richness, Heritage Sites, Al-Baha Region. 


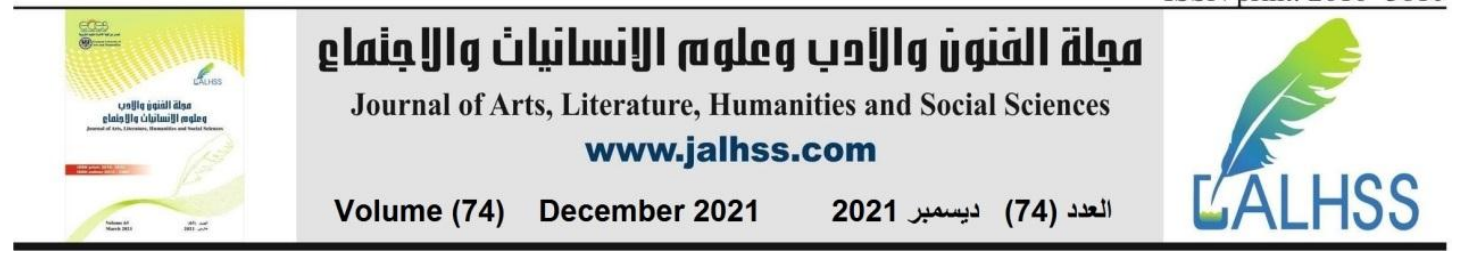

\section{Introduction:}

Al-Baha region is one of the most important regions of the Kingdom of Saudi Arabia, as it is a region in the middle of the country of Tihamah and Sarat, which extends from Asir region in the south to the country of Taif and Makkah alMukarramah in the north, the region is distinguished by its historical dimension and its cultural depth, as it embraces many historical places and archaeological buildings that were and still the witness on the time periods in which the city lived.

The tourist in Al-Baha region sees much of its material history that is represented in its buried monuments in some of the ancient urban and ancient civilization centers, and its surface monuments that are presented in its rock carvings and drawings, in addition to its villages, caves, cemeteries, popular markets, dams and ancient roads.

These fields can attract large numbers of tourists if they are rehabilitated and opened for tourism activity and the provision of the infrastructure and tourist facilities that serve this aspect.

Based on the foregoing, we aspire to draw attention to bringing about tourism development through (revival tourism), which is carried out through the development of archaeological sites as a means to achieve comprehensive development to revitalize the economic cycle, and to encourage development for the region within a sustainable development to ensure the revival of the monuments and the preservation of their authenticity.

It is possible to clarify some of these great historical scenes that represent a wealth for the region, by shedding light in this study on introducing the city through the study of its location, and the factors of its emergence, as well as a presentation of some archaeological sites, a review of the possibilities of tourism in them, and the extent to which these capabilities are employed for tourism purposes, and then standing on the most important problems that visitors suffer from and suggesting solutions in order to advance and upgrade them to satisfy the visitors' needs, and activate the tourist demand for them.

The researcher could not specify a specific time to study the antiquities in Al-Baha region, due to the unavailability of chronological and archaeological history for many of them, therefore, focus was placed on some of the monuments in the region, so that the study time extended in different eras, and the focus was on some of them without the other, due to the scarcity of historical information about them.

It is not possible through this study to contain them completely, but will talk about some of them based on the types of heritage architecture in them.

There are two types of architecture that go back to the past in the region, and they were dealt with in the subject of the study, they are : the historical architecture that are buildings that were built in the distant past that do not now perform the functions for which they were built, such as the ancient village of Thee Ain, the village of AlMalad, and the heritage architecture, which are buildings that were built in the recent past and it is still performing the functions for which it was built, such as the heritage village of Al-Atula and Qasr Bin Raqosh.

These sites differ from one place to another as a result of what is determined by the nature of the site and its cultural dimension, and they were chosen because they have 


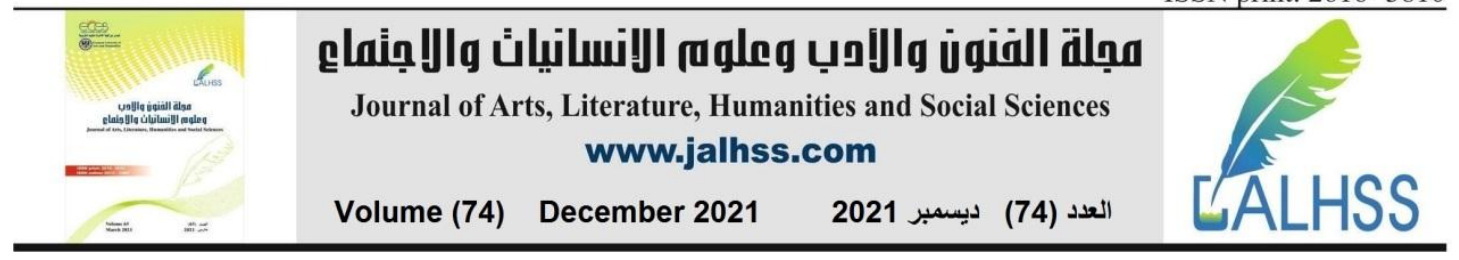

various historical dimensions to cover the historical and archaeological aspect of the area.

Therefore, the researcher made a historical and topographical archaeological diversity, so she preferred to mention an archaeological village in the south of the region (Al-Mald village) - and a village in the middle of the region (Balraqosh village), and village in the north of the region (the archaeological village of Al-Atula), and the archaeological village of Thee Ain in the southwest of Al-Baha region in the Tohami sector.

From this point of view, the study came in a different time range, and its purpose is to list and document the archaeological and historical monuments.

Many studies were directed to the study of architectural heritage in the Kingdom of Saudi Arabia, and the role of antiquities in the tourism development, including the study of Abdul Rahim Ali Al-Ghamdi (1996 AD), which aimed to find out the extent of a relationship between the social characteristics of the tourists and their motives towards choosing tourist areas. Also, some studies also dealt with the study of the history of the region through historical ages, which was one of its most important objectives is to highlight the historical role of the region and document the sayings of scholars and Western travelers to the region, as the study of Ghaythan bin Ali Jeries (2019 AD) aimed to clarify the importance of the history and civilization of the region since the pre-Islamic eras and through the early, medieval, modern and contemporary Islamic eras, it also presented aspects of the social, economic and cultural life, as the study dealt with the antiquities of Al-Baha region, including the destruted antiquities and the antiquities that have not been recorded so far in Al-Baha and its environs.

There is another direction went to search for an archaeological architectural study of Beida valley in Al-Baha region, as in the study of Awad bin Ali Al-Zahrani (2004 $\mathrm{AD}$ ), which aimed at an archaeological architectural study of Beida valley and the factors that affected the construction, and the study of Abdul Rahman Al-Ansari (2009 AD) aimed to clarify the history and geography of the region, which aimed to define the archaeological and aesthetic characteristics of the region, also the study of Basil Ahmed Al-Fatli (2016 AD), which aimed to clarify the role of antiquities in the tourism development and activate the role of antiquities in the tourism development of Al-Ahwar region to improve the economic, social and environmental situation, and the study confirmed that the investing of the potential of the site and the surrounding areas of the archaeological sites is considered as one of the most important elements of the revival tourism development that works hand in hand with preserving the historical urban products and their privacy, and the tourism development cannot be achieved without the social sustainability, in addition to the study of Taghreed Saeed Hassan, which aimed to identify the reality of the archaeological sites and the Islamic legacies in the city of Mosul and their distribution, in addition to providing indicators of a procedural nature to develop the tourism role for the archaeological sites in them. 


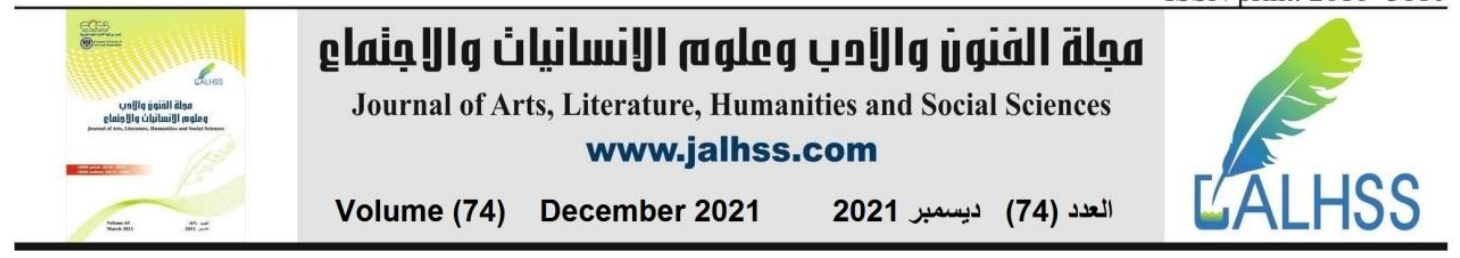

\section{Research problem:}

Al-Baha region is one of the regions with a long history and this is evident through its archaeological and historical sites, but it suffers from a shortcoming in activating the role of antiquities in the development of the cultural tourism, so the study problem can be formulated in the following question:

- Does Al-Baha region have tourist potentials to develop the heritage and historical tourism in the region and take benefit from it in opening new fields of tourism around the archaeological sites?

\section{Research aims:}

1- Studying the reality of the archaeological sites state in the region.

2- Providing procedural indicators to develop the tourism role of the archaeological sites and legacies in the region.

3- Highlighting the archaeological tourism potential of Al-Baha region that can help expand the strategic plan for tourism by adding new tourist areas around the archaeological sites in the region.

4- Activating the role of the antiquities in the tourism development to improve the economic, social and environmental situation of the region.

5- Shedding light on the importance of the archaeological tourism and the most important tourist areas in the region with a historical dimension, and the obstacles it faces, and this in turn helps provide a vision for those interested in Al-Baha sector to work on finding appropriate solutions for it.

\section{Research importance:}

1- Knowing the most important tourism potentials that can contribute to develop the heritage tourism in Al-Baha region.

2- Investing the natural, archaeological and historical elements as elements of tourist attractions.

3- Spreading the archaeological awareness among the citizens and informing them of the importance of the region's heritage and civilization and how to preserve it.

4- This study is agreed with the state's directions towards encouraging and developing the domestic tourism in the light of the $2030 \mathrm{AD}$ vision, and that by defining the potentials of tourism in the Al-Baha region and proposing the adoption of a tourism planning approach to take care of the historical monuments and archaeological sites in an attempt to work on activating and developing the tourism sector.

\section{Research terms:}

The archaeological sites and the historical places:

It is the civilized receptacle of culture, where it preserves the essential characteristics of the region that distinguish it from others, and it considered as an important element of the tourist elements as it is the available human-made raw material that attracts tourists to it all year long in Sarat and Tihamah Al Baha and is not subject to seasonality like other types of tourism. 


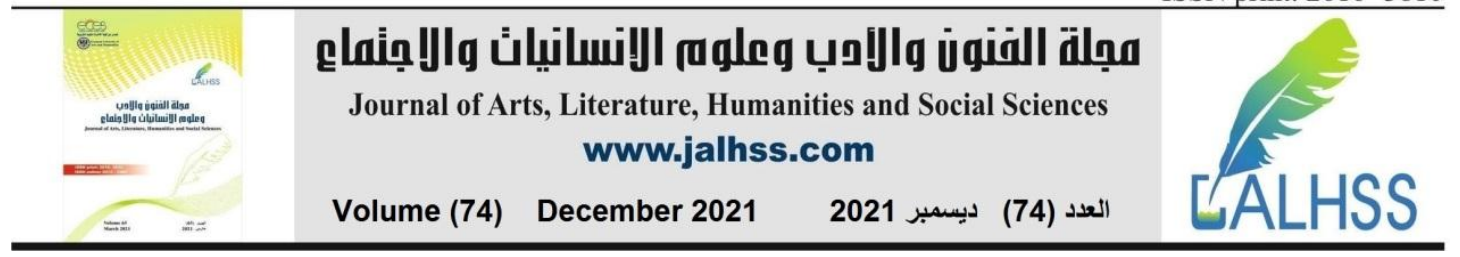

\section{Research hypothesis:}

The possibility of establishing archaeological tourism in the region after its exploitation, maintenance, reactivation and formation to revive and develop sites in the region, and contribute to develop the city, and provide an important source of income for the people of the region.

\section{Research methodology:}

This research followed the analytical descriptive approach to reach the goal of the research and to prove its hypothesis through the theoretical and practical framework.

\section{Research limits:}

- Spatial limits: Al-Baha region is located in the southwest of the Kingdom of Saudi Arabia, between longitudes 41 and 42 east, and latitudes 19 and 20 north.

- Time limits: the period from 1/11/1440 AH until 1/12/1441 AH.

\section{Theoretical framework:}

\section{The geographical framework of the study area:}

\section{Location:}

What is meant by the term Al-Baha is the square, and it includes the square of Aldar and its middle. It located in the southwestern part of the Kingdom of Saudi Arabia, between longitudes 41 and 42 east, and latitudes 19 and 20 north. It is bordered by the Asir region from the south and east, but in the north it is bordered by Taif Governorate, from the east by Bisha Governorate, from the south by Al-Qunfudhah Governorate, and from the west by Al-Laith Governorate. The city of Al-Baha forming the capital of the region in the modern era, and from the administrative side, it consists of six governorates, four of which are in Al-Sarat, which are the governorates of Al-Jarshi, Al-Aqiq, Al-Mandaq, and Al-Qura, and two in Tihamah, which are the governorates of Al-Makhwah and Qolwah.

\section{Surface features:}

The surface of Al-Baha region is divided into two main geographically differentiated sectors, the Sarat sector and the Tihamah sector. Also, Al-Baha region in terms of its surface features consists of the following:

\section{First: Al Sarat:}

It is called Sarat Mountains or Hijaz Mountains. The Sarawat Mountains that are located on the Saudi lands, extend from the Jordanian borders in the north to the borders with Yemen in the south, with a length of approximately 1,700 km. Al-Baha region is located on the Sarawat Mountains, and includes the highest peak in the region (2614 m) west of the village of Qarn Zabi.

And, spreaded in it the green valleys and the shallow water basins in it, represented by the valley of Turbah Zahran that starts from Beidan and Qarn Zabi and ends in Turbah Al-Baqoom and is based on it most of the cities and villages and is called (Al Sha'af), and among the most important cities located in this strip are: Al-Mandaq, Al-Baha, and Baljurashi. As for the other part of Al-Sara is called The Eastren Sarat, and it extends from Al-Sarat mountians to the east of the region and the end of its borders, 


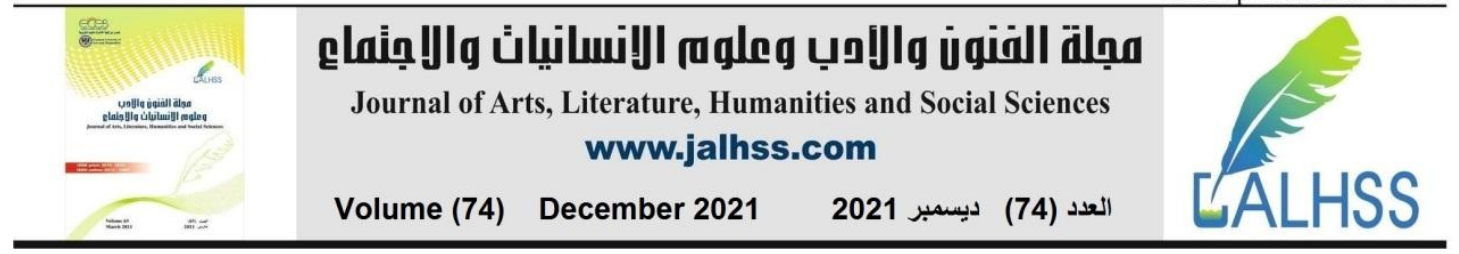

and most of it is in the form of a plateau with a height of $1900 \mathrm{~m}$, and it penetrates the main valleys such as Rniah valley, Tharad valley, Kara valley, and the city of AlAqiq.

\section{Second: Tihamah:}

The Tihamah plain extends along the coast of the Red Sea, and the length of the Tihama plain in Saudi lands is $1700 \mathrm{~km}$ (10). Tihamah is divided into two parts, the upper and the lower. The upper part lies below the slope of the mountain chain separating Sarawat and Tihamah with height ranging between 300-400 m above sea level. Population communities concentrate on banks of these valleys and at their convergence points. The most important mountainous heights are the Nahra Mountains in the north, Shadwan the upper and the lower, Wanis and Raya, and Al Fara'a, and they are not without the presence of many residential areas such as the areas of Al-Hajra, Al-Sha'ara, Qilwah, Al-Makhwah, and Batat. As for the lower Tihamah, they are coastal plains bordering the Red Sea, with a width of 4-30 km, and they are presented by Nawan, Al-Green, Yebs, and Lower Al-Suwaidi.

\section{The climate:}

The climate of Al-Baha region is divided into two different main parts according to the different terrain, they are as follows:

$>$ The climate of the Sarat Highlands is mild in summer and cold in winter, and the temperature increases as we head east towards the interior plains.

$>$ The climate of the Tihamah plains is hot in summer and mild in winter.

\section{Historical framework:}

When the state of Islam was established in Al Madinah Al Munawwarah, the Ghamid and Zahran tribes were among the forerunners of Islam, and the region was linked to the events of the Islamic era inside and outside the Arabian Peninsula, and Al-Baha region was politically subjected to some of its sheikhs who had links with the nobles in Al-Hijaz, and some of the Ottoman forces in Al-Hijaz and Yemen during the $7^{\text {th }}$ century AH / 13 AD.

At the beginning of the $13^{\text {th }}$ century $\mathrm{AH}$, the political situation in the southern region was characterized by turmoil and insecurity, at this time of the spread of chaos, the reformist Salafi call had raged on the horizon and appeared in Najd at the hands of the two imams Prince Mohammed bin Saud and Sheikh Mohammed bin Abd Alwahhab, and its great effects extended to the regions of Al-Baha, Asir, Jazan, Qunfudah, Najran, and some parts of the country of Yemen. The end of the second decade in the $13^{\text {th }}$ century AH / 19 AD did not come until most of the countries of the south became loyal to the Salafist call, and the influence of the first Saudi state extended over large parts of the Arabian Peninsula, in the second and third decades of the $13^{\text {th }}$ century AH / 19 AD, the country of the Hijaz, the country of Tihama and the Sarat came under its rule. In light of the political supremacy of the first Saudi state and its expansion, what was of the Ottoman Empire but to confront it through its governor of Egypt Mohammed Ali Pasha, in the middle of the third decade of the $13^{\text {th }}$ century AH -19 th century $\mathrm{AD}$, and his first campaigns targeted the land of Al-Hijaz and the countries that located in the south of Taif, where it became clear to Mohammed Ali that the 


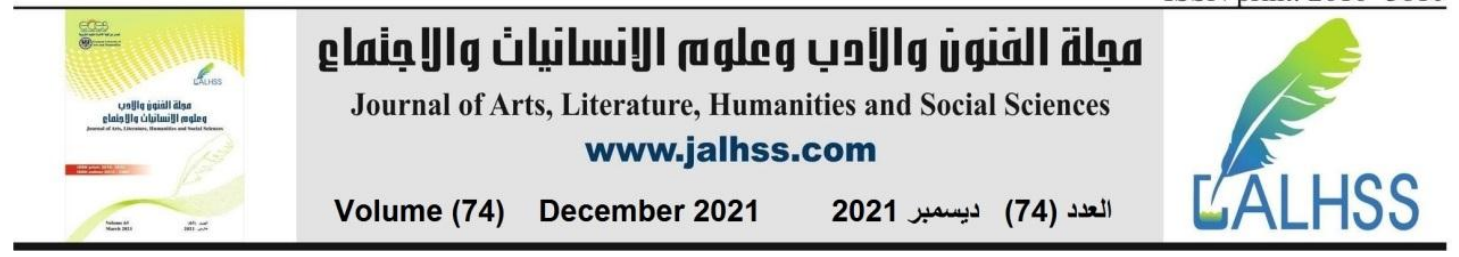

largest extension of the Saudi forces comes from the countries of Ghamid, Zahran, Asir and its environs.

His armies faced many obstacles with the Ghamid and Zahran tribes that confronted him. As a result of the region's richness in agricultural and livestock bounties, the Ottoman Empire was eager to control it. As stated in many documents and correspondences between the princes and leaders of Al-Hejaz and the Ottoman government in Astana and Egypt, and it explicitly mentions the importance of Ghamid and Zahran economically and the necessity of working to bring them into the possession of the Ottoman forces in Al-Hijaz. In the midst of this political chaos, King Abdul Aziz bin Abdul Rahman Al Saud launched his campaigns to reunite the country, the people of the study area had their contribution to the unification campaigns, which resulted in the establishment of the Kingdom of Saudi Arabia in $1351 \mathrm{AH}$, and Al-Baha region joined under Saudi rule in 1338 AH-1920 AD, in the year $1383 \mathrm{AH}-1963 \mathrm{AD}$, it was renamed the Emirate of Al-Baha region, and it was the beginning of an announcement for it to take its share of the cultural and economic renaissance with all its services. Through these political and security events, we have a clear impact on the formation of the village in the area and its urban character, the defensive character that was built primarily for defensive purposes.

\section{Functional importance of heritage places in the region:}

Al-Baha region includes many famous landmarks with a historical and archaeological dimension, and gave them features through which they tried to preserve their importance and originality, and the great similarity among them in terms of the strength and immunity of construction, and most of these sites are similar in the style of planning and construction for all the elements of the architectural units in them.

The impact of environmental, social and security factors is evident in the diversity of the traditional urbanization in the region. The urban structure in the highlands, buildings in it are made of stone and they have high heights and mostly follow the pattern of adjacent buildings, these buildings appear in many villages at the top of the mountains without large spaces between them, and narrow and winding lanes appear in them. Also, the social factors, especially customs, traditions, values and even tribal affiliations, overlap in affecting the urban structure, residential shops that are important elements in Al-Baha region often reflect the nature of tribal affiliation, as the population belonging to a tribe get gather in one area that contains its places of worship, its markets and its baths. The markets not only played a major role in economic life, but also extended to social life, and are often linked to the mosque in order to express the formulation of the great interaction between the spiritual and material aspects. Therefore, the markets and commercial streets were among the most important elements that attract tourists.

Before reviewing the most famous monuments and historical sites in Al-Baha region, it is better to address a simplified and brief explanation of the most important elements of the architectural heritage of traditional architecture, which can't be separated in any way from the cultural, social and economic data that affected it, nor about the person of this region who developed it and it was a reflection of his 


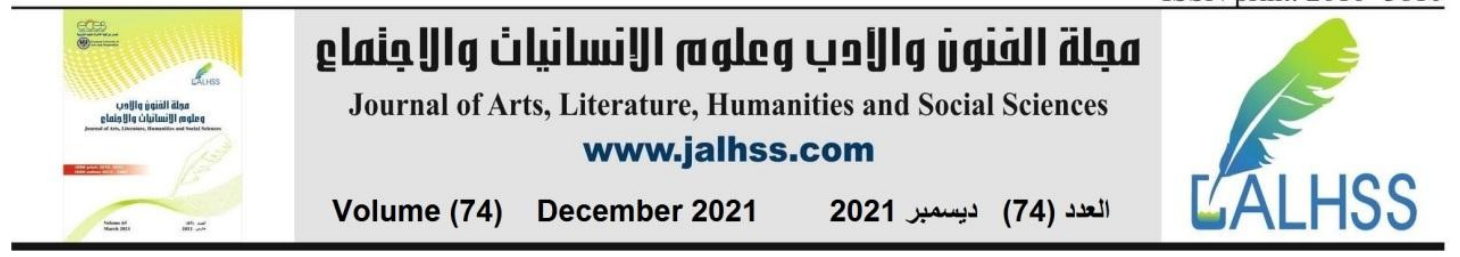

customs, traditions, religious and social values. These architectural structures are divided into:

\section{Traditional house (the stone buildings):}

The old buildings and their remains are spread in most parts of the region, especially the valleys and the areas near the agricultural terraces, due to the availability of raw materials for construction. The construction team consists of three or more people specialized in construction because it is a skill that requires accuracy and knowledge of the shapes of stones and the appropriate locations for them. The stone houses consist of different floors according to the financial condition of the individual and they ranged from one floor to three floors and sometimes up to three floors and are characterized by their ability to withstand heavy rain, and the ground floor of the house is dedicated to livestock and their feed, also this floor used to store grains and livelihoods. The first floor is designed for living and receiving guests, and part of it may be devoted to store the agricultural yields, The second for the family and its members if the building is three floors, but If the house has two floors, then the upper floor is divided between the family rooms, one room for receiving guests from men and the kitchen.

The components of the house from the outside vary in their external appearance according to the social status of the owner and the area of the house, and there aren't ornamental qualities such as decorations, for example. Simplicity prevails and the cost is less on most of the elements. The common feature among them is the use of hard stone when constructing the external facades, and these facades rise between 15 and 20 meters approximately in a coordinated and regular manner. The external facade contains the entrances, and the entrance opening is widened and narrowed according to the size of the house. There is a recessed entrance in some houses to preserve the privacy of the family inside. So that the guests can't see who is sitting inside the house, and this is a result of the jealousy of Muslims stemming from the teachings of Islam for their sanctities and their women, and it appeared clearly in the design of the facades of the houses, and the living model for this type of building is what is located in the ancient village of Thee Ain, and the building of Bin Raqosh palace in the village of Bani Sar, and The archaeological village of Al-Atula. Also, small areas distinguish some houses here, where the area of most buildings does not exceed 6 by 7 square meters, in addition to the low height of the floor $1.50 \mathrm{~m}-1.70 \mathrm{~m}$, and the presence of very narrow doors and windows in the form of small openings that range from a crack that does not exceed $10 \mathrm{~cm}$ in width and $60 \mathrm{~cm}$ in height.

Standing on most of the remains of old houses at the present time, we notice the collapses in the center of the building away from the existing corners, and some are columns of the building, but the roofs are exposed and threatened with collapse. Most of the houses contain only the rocks of the buildings, but the timber of the roofs, doors and windows does not exist. Therefore, the focus in this study was on the old houses that still maintain their cohesion due to the possibility of applying the results of the study on them, as mentioned above. 


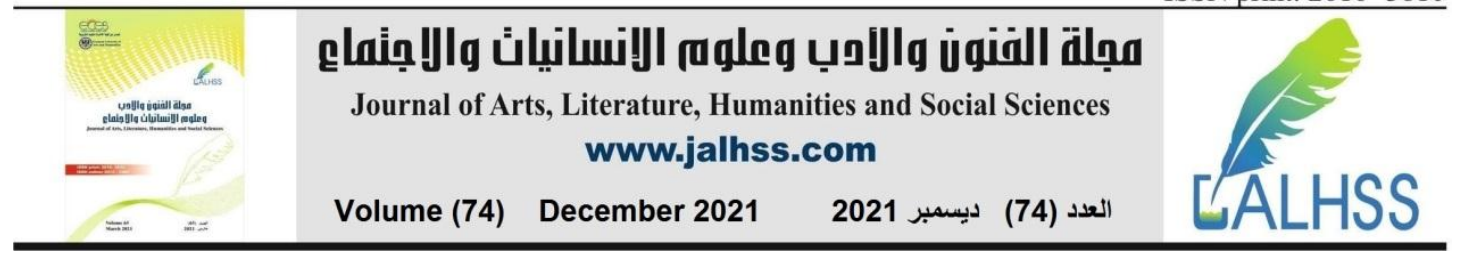

\section{2- Markets:}

The emergence of local markets as a result of local need, and then became active and became a destination for foreign trade. There were many merchants from the region who had trades that reached for import and travel to the cities of Makkah and Jeddah and then to the foreign countries such as India, Abyssinia and Sudan. The market is held on a certain day of the week throughout the year, and it has rules and regulations that shoppers abide by, and it is supervised by the elders of the village and becomes inherited to them by supervision and observation. Al-Baha markets are like other markets in the rest of the Arabian Peninsula, including Hebashah market, which has taken on a regional character considering that it is the largest market in the region, and it is narrated that the Messenger aلd walle was a merchant in it, and it is located in Tihamah in the homes of Bariq, and the Islamic sources reported that it was prosperous before Islam, and it remained so until the end of the $2^{\text {nd }}$ century AH. Its activity is not limited to supply and demand in goods for sale and purchase, but is also a destination for seasonal forums and periodic conferences, where pamphlets and speeches are broadcast, and poetry is sung in it. Also, handicrafts are presented in it, literary and poetry evenings are held, and folklore is held in it about the regions of the Kingdom of Saudi Arabia.

The activity of the weekly markets has continued until the present time. In Sarat AlBaha, there are a number of them. The following is a simplified review of four of the important markets in the region, as follows:

Baljurashi market, which is held on Saturday every week, and it is located in the center of Baljurashi city, and it was a destination for merchants of Yemen and countries of Al-Hejaz, and it is one of the oldest and largest markets in the region. It is still standing to this day, retaining its position for more than 500 years, and its goal is to revive what has perished from the ancient folklore, and bringing back what the market was like in the past, and it was an important commercial destination, and a site for reconciliation between tribes and opponents, a destination for seeking knowledge, and a site for commercial exchange.

* Al-Mandaq market: It is held on Saturday, and is frequented by the people of the area and the surrounding areas, and it is still existed to this day.

* Rubuaa Quraish market: It is sometimes known as Rubuaa market and it is held every Wednesday in Al-Atula Governorate, northeast of the region.

* Thursday market: Al-Baha market: It is located in the center of Al-Baha city, and it is still existed until now with its commercial activity.

* Raghadan market: It is located in the center of the village of Raghadan, and a meeting point for the people of the area and the neighboring areas of Sarat, Badia and Tihamah since ancient times, and it is an important station on the Yemeni pilgrimage road. It is characterized by the diversity and density of the exhibits that shoppers come to from different parts of country, and nothing remains of it except the stone shops. The General Authority for Tourism and National Heritage worked to restore what had been worn out in the same traditional architectural style of stone, mud and wood, and it includes more than 33 shops and commercial stores in which foodstuffs are sold in addition to local fabrics and manufactures, in addition to holding feasts and 


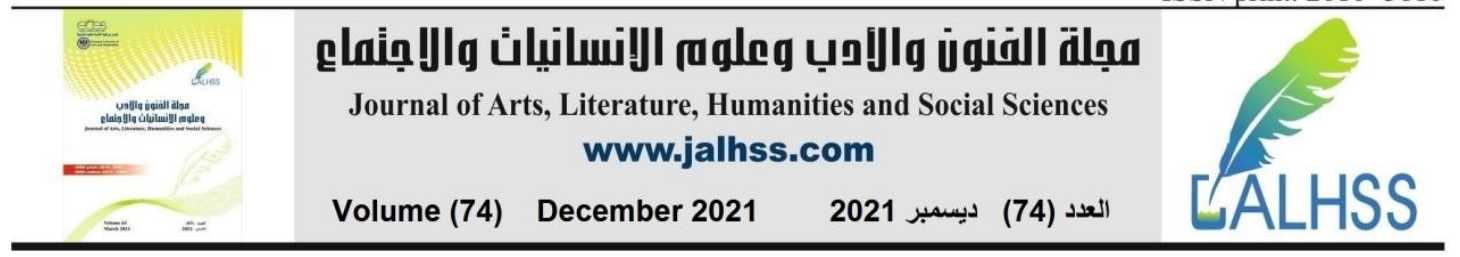

cultural and public events in it. Recently the Eid activities were held for Al-Hajj season for the year $1440 \mathrm{AH}$.

\section{Forts (defensive towers):}

Defensive buildings are spread in the villages of Al-Baha region, and there is no small or large village that does not have one or more towers and is known as (the fortress), as a result of the tribal conflicts that prevailed before the period of unification of the Kingdom of Saudi Arabia. Its uses were varied as its defensive and combat mission to monitor the enemy, and it may be a refuge for the tribe's members at the time of wars, in addition to monitoring farms and preserving agricultural crops, so it was built near agricultural lands, and thus it would have combined the three objectives: a residential, agricultural, and monitoring goal. The construction is often done in a collective way that shares in it people of the village or one clan, and thus its joint ownership of the village or family (the weft), using mud or stones or both, so that its foundation is built with stones, and its construction begins with a wide square base, then contradicts in its capacity as the building rises in a geometrical shape that maintains on the balance of angles and dimensions. Its height may be between 18-20 meters, and the towers at its top are decorated with geometric decorations in the form of triangles, and the decoration is done in contrast between the color of the stones used in construction, which are mostly black and gray, and the white quartz stone that is used in decoration. This fort has one door and one key, which is entrusted to the head of the family or the deputy of the village, and the roof is usually surrounded by such a belt, and in the four corners, which are more prominent than the rest of the roof, large quartz stones are placed. The advantage of building the fort from the outside is that it is on one azimuth, with no room for an opportunity to climb from the outside, and devoid of windows except for its upper floors, and the windows are small, and the size is in the form of a small triangle. The number of towers in $\mathrm{Al}$ Baha region reaches about four thousand, and the most famous of them are the two fortress of the village of Al-Malad, the fortress of Al-Muqatil, the fortress of Rasaf in the village of Bani Sar, the fortress of the village of Al-Fadla and the fortress of the Migration of Al Jaber in Munif valley. The village has more than one fortress, and in symmetrical and with strategic locations, and the maintenance and preservation of the fortress is a joint responsibility of the people of the village.

Spatial analysis of the most famous archaeological sites and historical monuments in Al-Baha region:

Al-Malad Village - Thee Ain Archeological Village - Al-Atula Heritage Village Ibn Raqosh Palace

The sites differ from one place to another as a result of what is determined by the nature of the site and the assumptions of the place and its cultural dimension, so we will choose some archaeological sites with various historical dimensions to cover the historical and archaeological aspect of the region, so it cannot be covered in such this small research. Therefore, I made a historical and topographical archaeological diversity, which represents historical architecture and heritage architecture, so I preferred to mention an archaeological village in the south of the region (the village of 


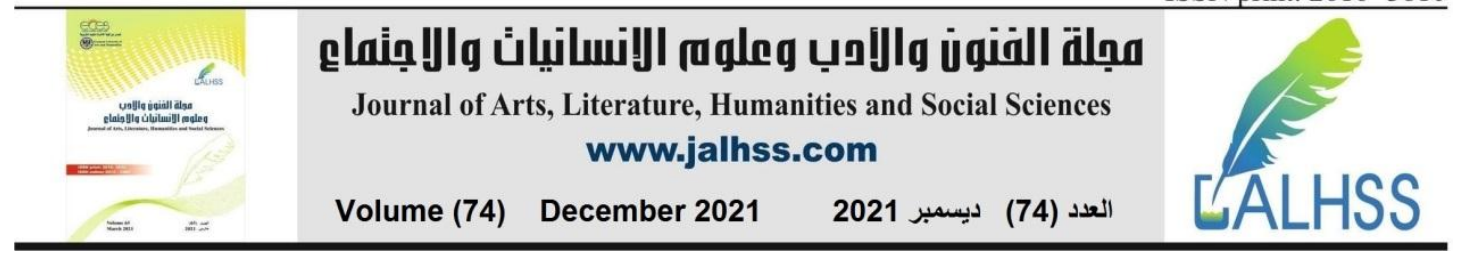

Al-Mald) - and a village in the middle of the region (the village of Balraqosh), the village in the north of the region (the archaeological village of Al-Atula), and the ancient village of Thee Ain in the southwest of Al-Baha region in Tihamah sector.

1- The village of al-Malad (in the fortress of al-Malad): It is located one kilometer east of the town of Al-Dhafeer, and about 3 kilometers to the southeast of Al-Baha. It is located on a high hill 2081 meters above sea level. Its inhabitants are from the Bani Abd Allah tribe in Sarat Ghamid. The modern buildings have spread to the south and east of the old village, and the village overlooks the (Al-Baha - Baljurashi) road. The village is also distinguished by the lack of modern materials for its old buildings, and the presence of two adjacent forts at the top of the hill surrounded by old houses - as it was said -for two brothers are equal in everything, even the defensive forts, one of them is in the south and is located in the northwest corner, which is located inside the courtyard of one of the two-storey houses, the door of the ground floor is towards the south, as for the door of the upper floor, it is through the open courtyard from the north side and it has a high level of about two meters from the floor of the ground floor, therefore, there is a staircase of stones starting from the west of the courtyard not far from the fortress and heading towards the south, then east to enter the only main door of the second floor, and from the beginning of this entrance there is another staircase to go up to the roof and it has a door with a very narrow opening of about 70 $\mathrm{cm}$. Inside the first floor there is a fixed wooden staircase that ascends through another opening similar to the one in the lower floor that leads to the next floor and so on. Thus, it contains four layers, with each layer having four towers, two of which are in the southern wall and two in the eastern wall, and it protects the houses from the east and south.

The other fortress is located from north to the southwest of one of the houses, half of the fortress is inside the house and the other half is outside. All the grounds of the ceilings are timber and mud. Most of the buildings are not good and need restoration, while others are dilapidated, and there are some distinctive landmarks that have been replaced and renovated, such as the mosque. The beauty of the village, the consistency of its structure, and its uniqueness are reflected in the presence of the two fortresses at the top of the village, as if it were the emblem of the region, which gave it a distinct and unparalleled shape. Some likened them to the two world trade towers.

2- Bin Raqosh House: It is located in the village of Bani Sar, within the current urban area of Al-Baha city, It is considered an architectural masterpiece in the region and one of the oldest palaces built in the year $1249 \mathrm{AH}$, and witnessed the visit of King Saud bin Abdulaziz to the bin Raqosh family in 1374 AH, and the bin Raqosh Palace constitutes an integrated residential system of houses and their accessories "a school, a mosque, horse stables, watering wells, and orchards", which were limited to five buildings, a mosque and a private housing building for workers, and four houses of them are united by one courtyard, and the fifth house outside the courtyard fence. The mosque is located in west of buildings number (2), and the house number (1)is considered the largest house of Ibn Raqosh, and in the middle of the building is a large courtyard to which the doors open. This building is characterized by the great height of the john (2). It consists of three floors and its facade is eastern. It consists of 


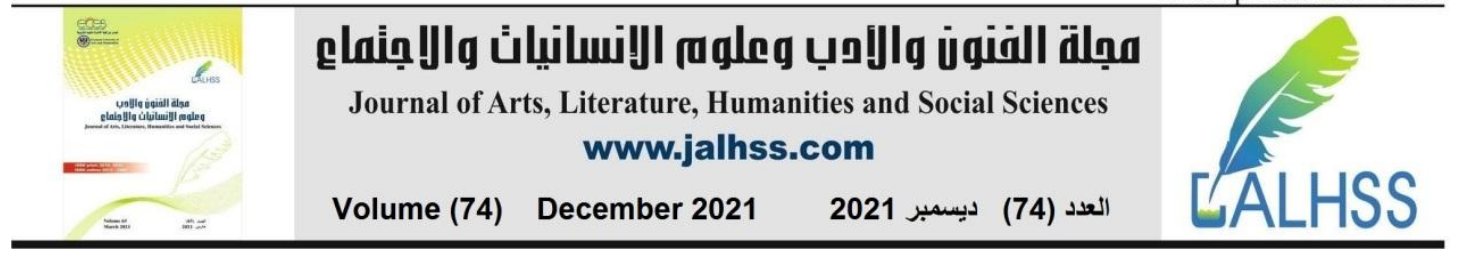

three floors and its facade is eastern, the northern facade of the building contains a large door in the ground floor, and next to it on the eastern side is a main staircase that ascends to the first floor. As for Building number (2), it is located in the middle of the courtyard and consists of two floors, and its main facade is southern and has a large, wide door in the middle, and there is an external staircase from one direction.

There is also a square in the ground of the front council of the ground floor in the southwest corner that leads to a ground tunnel that leads to a ground building (basement) located in the west of the building that was used as a prison, and the opening and the tunnel were used for the passage of prisoners from the courtroom to the prison, which has an external door that leads to the public road, and it was called (herds). On the upper floor there is an official bathroom, which is one of the oldest bathrooms that began to be implemented inside houses, and it has a hole to exit the water to the outside. In the northern wall of the ground floor there is a small opening that was used to pour water from outside the building into its interior to pour into what looks like a basin for washing and so on. It is similar to the bathroom in the archaeological village of Al-Atula. Building number (3) consists of two floors that may have been used to house some relatives, as for the ground floor it was a place for sleeping horses and other livestock. Building number (4) is located in the far north side of the buildings, and it has been used as a school for boys for many years, and in its courtyard there is a small pool that students used to perform ablution. Building number (5) that is the only building outside the main (courtyard), and links to building number (1) with a wooden bridge that connecting them in the upper (first) floor. It consists of two floors and its main facade is towards the north, and it has a small annex for hospitality and coffee, and next to it from the north side is the main staircase leading to the second floor. The most important feature of this building is that it contains a large tribal council for holding major meetings of the tribe, and a warehouse next to the council for storing public materials. There is a separate coffee site outside the building on which servants work and serve Arabic coffee, and the second floor is used as a private residence for guests, with a bathroom attached to it, and it is linked to the Sheikh's residence by a suspension bridge that workers use to serve foods. There is also a mosque designed on the side of the road for easy access, and it was equipped with its own toilets and ablution places, and it was supplied with water from its own well that was dug inside the mosque's facility to ensure that it would not be interrupted. The middle between the Sheikh's houses and the rest of the village houses consists of two parts, the mosque's courtyard and an external courtyard of the same area. As for the longitudinal building, it consists of ten rooms for the servants' accommodation, and they all open to the main courtyard. The General Commission for Tourism and National Heritage is working on restoring and rehabilitating it.

3- The archaeological village of Al-Atula: It is located in the governorate of villages between Taif and the city of Al-Baha that is approximately $35 \mathrm{~km}$ away from it. AlAtula is located on a plateau in the middle of Quraish valley that is located between two huge mountains; they are the eastern mountain and western mountain, while it is bordered in the south by the village of Al-Humaidan and to the north by the village of 


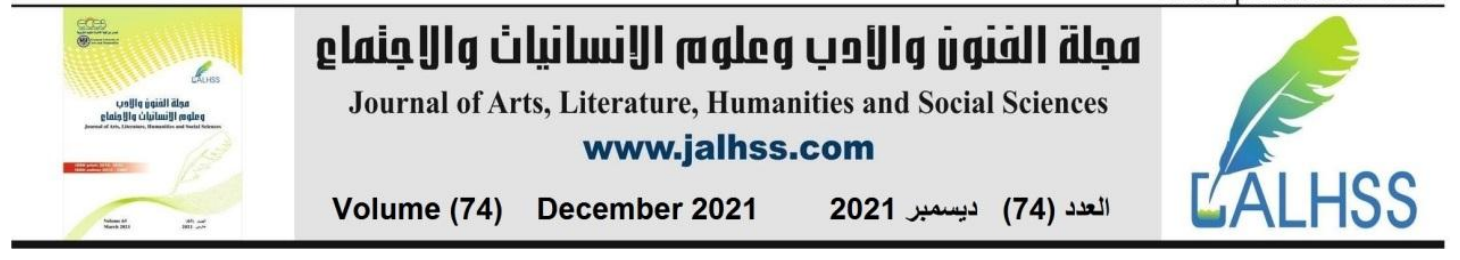

Bani Mohammed and Al-Qahad. The village overlooks a group of hills between two wide valleys that flow into Beida valley and Yanbaa valley on destance five kilometers south of the village of Al-Atula. The western valley in it was called Quraish valley, and the height of the western hills is 150 meters above the level of the Quraish Valley. The ancient village of Al-Atula contains several old buildings bearing architectural designs, the most important of which are the Sheikhdom's Palace and the prison attached to it, and the two forts of Al-Othman and Damas, in addition to the presence of the ancient architectural mosque of the village and the market of Rboaa Quraish, and the Al-Shamlani Museum that contains a diverse archaeological collection of ancient folk legacies and a variety of handicrafts, rare coins, folklore clothes and others, and we come to a brief detail of some Village components. The village contains about 40 houses, numbered by the Tourism Authority, because the village was surveyed by the Tourism Authority. Currently, the General Authority for Tourism and National Heritage, as part of its national transformation initiatives, is working to rehabilitate the heritage villages included in the action plan of the Custodian of the Two Holy Mosques Program for the Care of Cultural Heritage in AlBaha region, on the habilitating studies projects to restore the heritage village of AlAtula, as part of a number of projects to preserve the urban heritage in the region.

As for the headquarters of the sheikhdom, attached to it is a white fort called the White Fortress or the Constructed Fortress. It consists of five floors standing and valid for entry and overlooks the entire Quraish valley, and overlooks the historic Quraish market, so the sheikh of the tribe looked from this place to the market of Rubuaa, Quraish valley and the neighboring houses. The sheikh of the tribe oversees the area from the top of the fort, and the fortress is distinguished by the inscription of the doors, and it has a white material over the stone, which is known as plaster. There is a fortress adjacent to the fortress of Al-Mashikha, which is the Damas fortress. The date of its construction is unknown, and it is one of the highest fortresses in the southern region. It has a very high height, and due to its height, there were a number of floors that no longer exist except for minor traces of them, and there is a stone built at a height of 12-13 m with the inscription: Oh God, forgive Yahya bin Falah." and it is a non-dotted writing, and this is a great indication of the ancient fortress, because the dotting were not known in the Arabic language until the beginning of the $1^{\text {st }}$ century $\mathrm{AH}$. As for the village mosque, it is an old mosque with 14 pillars on its roof, and it is considered one of the largest mosques in the southern region, and this is evidenced by the commercial movement that the village is witnessing due to the presence of the AlRubuaa market, and it is intended for all the people of the region from countries of Ghamid and Zahran who stay a day or two before the market day. The mosque is distinguished from other mosques in the entire region, which is the presence of special paths for ablution, as there is a pool that draws water from the roof of the mosque, there are also 3 paths for the basins, a path for cleansing, a path for ablution, and a path for drainage, and it descends into the pond, and if water is scarce, it is brought near the well, then water is taken from the pond by bucket and poured into basins known as "al-hokr" (50), and the water level is equaly distributed in it, it is filled up and after ablution it is disposed of. There is a second stream called Al-Marosh, which 


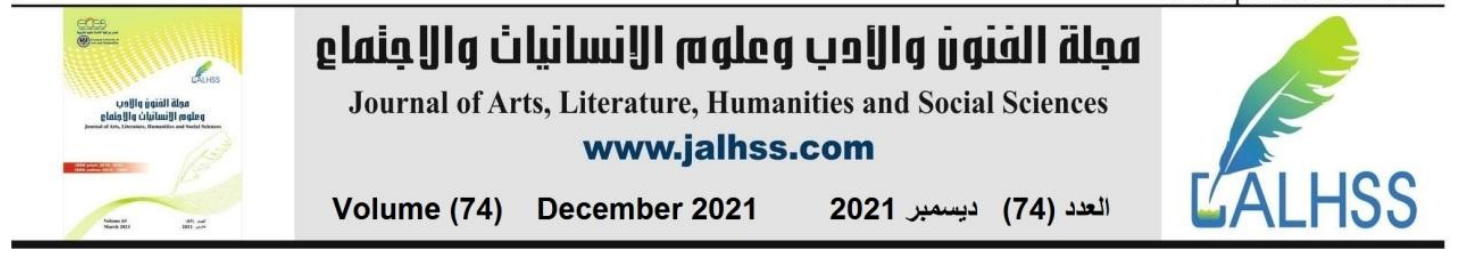

is not present in Al- Baha region, and perhaps it is rare in the southern regions as a whole. The water is poured into rooms in buckets that have drainage and an external stream, and they are about 6 meters away from the mosque, and it is mostly used by the elderly, especially on Fridays.

There is no doubt that the mosque played an advocacy and social role in the village, where it was a place where the people gathered to discuss any matter related to their social issues, and the mosque had a side staircase made of stones that connected to the roof of the mosque, and the muezzin perform the call to prayer, and his voice was heard in the valleys because the site was empty in the old time from the noise of cars. Al-Atula Mosque and its old mosque were restored within the project of Prince Mohammed bin Salman to restore the archaeological mosques in the Kingdom. "The restoration news site I saw it" and the restoration and delivery were completed. As for the school, it was "Katatib" and it was the focus of the parents' attention, until formal education entered it in $1372 \mathrm{AH}$ in the house of one of the village sheikhs from the Othman family. There are farms near the village where crops of wheat, corn and wheat are grown. Al-Shamlani Museum is an archaeological museum located in the village of Al-Atula in Al-Baha region, and it is considered one of the most important and oldest museums in the region, because it contains a diverse archaeological collection of ancient folk legacies, which vary between agricultural tools, ancient pots, weapons, tools for crafts and ancient professions, rare coins, folkloric clothes and handicrafts of wicker and weaving.

It is attributed to the Shamlan family, who established the museum by Sheikh Abdulaziz Al-Shamlani in the year $1435 \mathrm{AH}$ in the family's house in the village, to become a legacy for the family. The museum is supervised by Abdulaziz bin Saeed, who provides it with care and attention to all valuable holdings, which has been collecting artifacts for more than 25 years. It has obtained a license among five museums in the region from the General Authority for Tourism and National Heritage. The museum takes the shape and character of the old archaeological houses that were preserved by Al-Shamlani family. The ceiling covered with timber and lanterns hanging from it was preserved, the floor furnished with hand rugs and the walls tainted with mud that is an ancient paint used by parents and grandparents for hundreds of years, and it contains ancient archaeological artifacts, and its facade is side staircases.

These pieces were arranged in groups, each group representing a type of ancient handicrafts, such as: the silvers corner and hand-made silverware, the old weapons corner, the clothes corner, and the coins corner containing a large and varied number of old coins and banknotes that extends up to the year 95 AH to the Umayyad period, and the agricultural tools corner. It also includes other corners such as utensils, hospitality, old groceries, and others. The museum receives its visitors on specific dates with the museum management.

4- The Heritage Thee Ain Village: It is located in the southwest of Al-Baha region, $30 \mathrm{~km}$ towards the slope of the King Fahd Obstacle (Al-Baha Obstacle - AlMakhwah) to the north of Al-Makhwah Governorate with $20 \mathrm{~km}$, and it is located at an altitude of 760 meters above sea level. And, it is considered one of the citizens of 


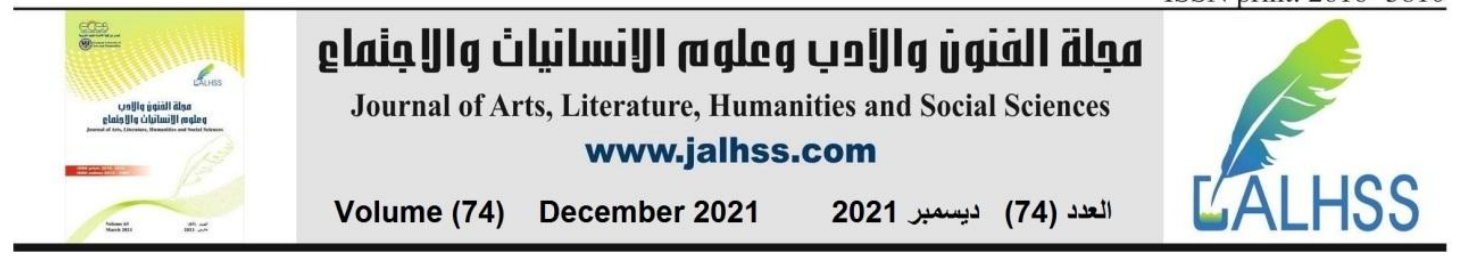

Bani Zeidan that includes each of the following villages: Al-Ayyash, Al-Tariq, AlJawh, Al-Masoud, Al-Sukran, Al-Asherah, Al-Awfa, Al-Marwah, the upper Ronah, the lower Ronah, Ghayad, and Al-Tarf. The buildings of Thee Ain village were built on an area of 18,567 square meters from local construction materials and from various elements, and among these elements are the protruding ends of some roofs of buildings, which are elaborately made of stone, and include 31 houses, and a small mosque, in which the houses consist of two to seven floors of varying size. It was built without foundation pits, but directly on the mountain slope, and all of them are built of stones, and their houses are roofed with juniper and sidr trees that were transferred from the neighboring areas and covered with stones (Al-Sali) where they are laid over the juniper trees and then covered with mud that blocks the pores and cracks of the stones, and their balconies are decorated with white quartz in the form of compact triangles, and the presence of two fortresses for defensive purposes. And inside some buildings there is a column of Sidr wood as the center column of the house, its length ranges between two to three meters, and at the top of it a crown made of wood so that it is made of the finest types of wood and adorned with ancient folk inscriptions, and then painted with what is called (bitumen) black with a bright color to protect the wood from eating of the moth. There is only one palace attached to it with a bathroom with a circular shape that resembles a fortress attached to the palace, which is Al-Ebad Palace, because they are the most financially able families. In the last hundred years, this palace was inherited by three sisters named (Al-Ebad's Daughters), who supplied the village mosque in the month of Ramadan with two sacks of dates daily; these dates are presented to the fasting people at breakfast. There is an inscription on it in one of the heritage palaces, specifically Al-Hussein Palace Al-Framleh (56). Dr. Ahmad Qashash was mentioned the history of this inscription goes back more than 3500 years. There are also three main roads, the first in front of the village parallel to the farms, passing through the village mosque, some paths to the village and farms branch off from it, and up to the waterfall area. The second: starts from the parking area currently north of the village and even behind the village to the east. And the third: from the spring of water (Al-Qila) area in the east of the village towards the so-called (Al-Quyouf) and it branches off into two paths, one of which is to up of the village towards its fortresses, and the other goes to the middle, passing through Al-Haramis house and Al-Yahmad house and down the village until it connects with the first road parallel to the agricultural facades.

We can say that the most important general characteristics of the archaeological sites and the historical monuments in the region in terms of location and construction are:

- The construction area is located on top of a mountain overlooks the village and its neighboring facilities, as we can see in the archaeological village of Al-Atula, Bin Raqosh palace, Al-Malad village and Thee Ain village.

- In the middle of the buildings is the house of the village sheikh (The Corporal) and the mosque, where it is hardly to find more than one mosque in each village.

- Building the weekly market and the cemetery in the outskirts, as is the case in the Wednesday market (Al Rubuaa) in Al-Atula. 


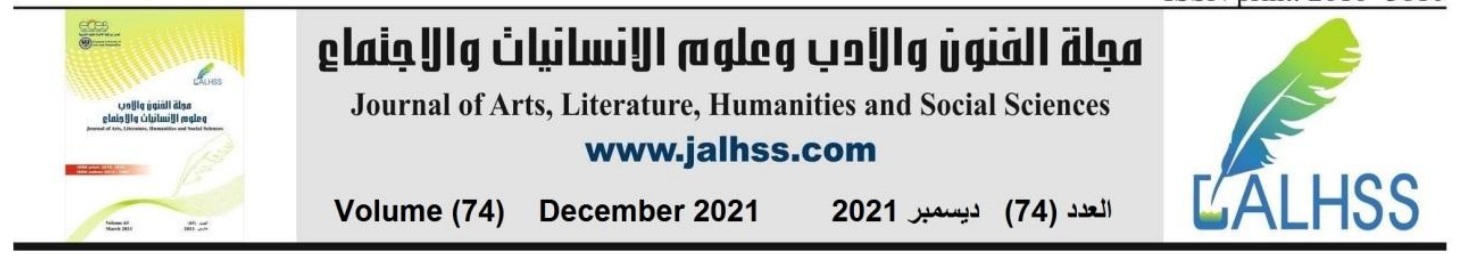

- The narrow and safe roads permeate the villages among the houses and some of them lead directly to the village farms and some of them penetrate the houses from inside the village to the farthest point, and perhaps the reason of making the roads narrow is to take the security aspects of the village, in addition to family rapprochement and social conditions to resist the conditions of fear, hunger, disease and wars.

- Building the fortress in a prominent and clear location in the village, mostly in the middle of the village for refuge in times of major wars. It is also used in some periods as a place to store grain and supplies for the village in times of adversity, as seen in the two fortresses in the village of Al-Malad and the archaeological Al-Atula village.

- The archaeological monuments that have been counted and talked about, and not other sites, are distinguished by the availability of a number of criteria that must be met in what is being preserved, the historical criterion in terms of the historical value of the building for the ability to preserve it, and the architectural criterion, its urban value, and how take benefit of it and preserved. The economic criterion is to achieve economic feasibility by preserving the building and its tourism marketing capacity, and to benefit from its returns.

\section{Results:}

1- Weak of the community services, infrastructure and neglect of the archaeological areas in the study area, which leads to undermining the tourism element.

2- The existence of challenges for the tourism development in some areas of the study represented in the eligibility of some agricultural areas for the villagers, which at the same time is one of the priorities that must be preserved and away from giving preference to development projects instead them.

3 - Investing the potential of the site and the surrounding areas of the archaeological sites is one of the most important elements of the revival tourism development that works hand in hand with preserving the historical urban products and their privacy, and thus several tourism patterns are intertwined to form together the elements of a larger integrated system to achieve the highest possible development.

4- The desire of the local population to pay attention to the archaeological areas within the cultural character of the region.

5- The lack of an integrated tourism plan at the level of the region that includes all available tourism resources from natural sites and civilization, historical and heritage manifestations.

\section{Conclusion:}

The presence of the archaeological sites and historical monuments in the region does not mean that it has become a center for tourist attraction. Rather, this process is followed by the so-called tourist industry for the archaeological site, which is organizing the site to become a center for tourist attraction through the production of tourist services required by visitors and tourists, and that through the tourism marketing of the site. We have previously listed the most important of these 


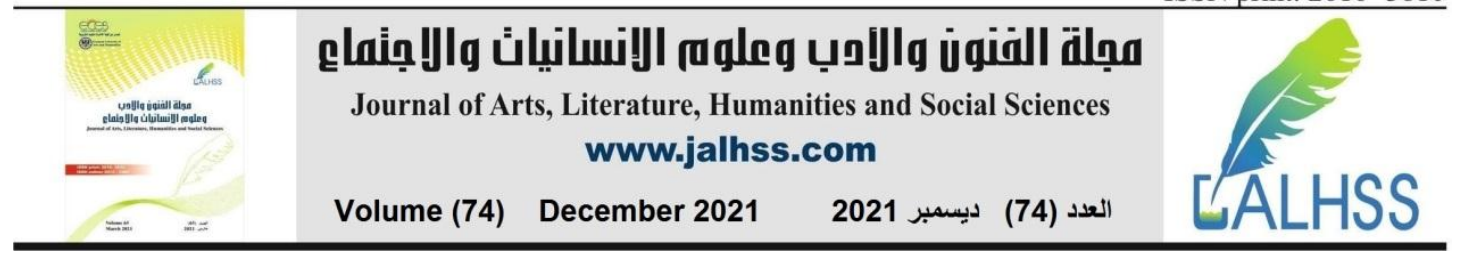

archaeological sites and not others, which may be suitable for the archaeological tourism industry due to their historical, social and political importance.

Al-Baha region is characterized by many elements and tourist potentials, when they exploited, multiple internal tourism can be established, such as natural resources and what distinguishes the region of the advantages of the location, weather, climate, geographical nature of surface, water, plant life, etc., and the historical and archaeological elements, and cultural and regional resources.

The region was concerned with social care and providing high levels of the integrated social services for family and childhood care in all rural and urban areas.

\section{Recommendations:}

1- Updating the national database, statistics and information for all urban heritage sites and the historical buildings in the region to serve all researchers, academics and government agencies, especially citizens, visitors and tourists.

2- Forming engineering committees that include many specializations, including the environment, as well as the archaeologists whose specialization must be compatible with the historical stages of the site to take decisions before conducting any development specific to any stage to examine the archaeological sites and their monuments and give proposals for the development and appropriate types of tourism and ways to invest them.

3- Community enablement that is in line with vision 2030 through facilitating the financial support for the citizens who residing in the old areas and helping them to rehabilitate their houses and shops, and protect the fertile lands adjacent to the archaeological sites, and encourage its investors and support them to supplement the tourism with their agricultural production.

4- opening the field in front of the foreign investment and giving it all administrative facilities, taking into consideration obligating him with conditions and signing agreements obligating him to preserve the environment of the region, its residents, and the tourists who coming to it.

5- Preserving the antiquities as they were in the past, and the first principle of the material heritage sustainability is to use what is available because of its impact on reducing resource depletion.

6- Increasing the popular awareness of the importance of the urban heritage and its protection through holding seminars, conferences and special popular demonstrations that focus on the urban heritage, and using the media with all its tools and channels to introduce the urban heritage and the importance of protecting it, and allocating programs, pamphlets and periodical publications that are accessible to everyone.

7- Spreading the archaeological awareness among the educational sectors through conducting periodic competitions at the level of education in the region, and making field visits and trips to the archaeological sites.

8- Activating more than one type of tourism and distributing various activities to most of the archaeological areas within axes and not concentrating all activities in one place and distributing trips on these axes. 


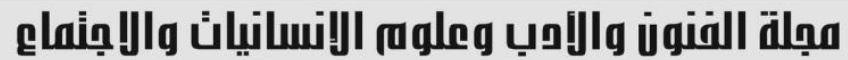 \\ Journal of Arts, Literature, Humanities and Social Sciences www.jalhss.com}

Volume (74) December 2021

2021

العدد (74)

9- Putting introductory panels in the archaeological and tourist areas, to inform citizens and visitors about the history of these places and their importance, and printing brochures and pictures that explain the history of the establishment and development of these areas.

\section{References:}

1- Ahmed Saleh Al-Siyari: Al-Baha is the House of Science, Jeddah.

2- Ibrahim bin Mohammed Al-Zayd: The presidency in the Zahran tribe since the $13^{\text {th }}$ century AH, 1st edition, 1419 AH/1998 AD.

3- Bader Adel Al-Faqir: Tourism Resources in the Kingdom of Saudi Arabia, Distribution and Characteristics, 1433 AH - 2010 AD.

4- Gamal El-Din bin Al-Majawar: The History of the Perspective Leiden: Brin 1950, 1954 AD, volume 1.

5- Gamaan Rashid bin Raqosh: The Historic Palace of bin Raqosh, $1^{\text {st }}$ edition, 1429 AH-2008 AD.

6- Hussein Mohammed Al-Ghamdi: Al-Baha in the Modern Era, Encyclopedia of the Kingdom, Volume 16 - Al-Baha Region - King Abdulaziz Public Library.

7- Khaled bin Mohammed Mobarak: The defensive towers in Al-Baha region in the Ottoman period, the towers of Al-Qura Governorate as a model, a master's thesis at King Saud University, Faculty of Tourism and Antiquities, 1438-2017, p. 11.

8- Zuhair Abdel Wahab Nawab: The Kingdom of Saudi Arabia: Facts and Figures, Jeddah, Issued by the Saudi Geological Survey Authority, $1^{\text {st }}$ edition, 1433 AH / 2012 AD, p. 14.

9- Saeed Ibrahim Al-Hoseel: Ghamed and Zahran Urban Treasures, Al-Madinah for Press and Printing, d, p, 1426 AH, Riyadh, p. 176.

10- Samir Nour El-Din El-Wattar: Indicators of Urban Heritage Protection in the Kingdom of Saudi Arabia, Assiut University Journal, 2015 AD, Issue 43, Year 6.

11- Abd Al-Rahman Sadiq: Geography of the Kingdom of Saudi Arabia, Riyadh, Dar Al-Marekh for publishing, volume $1,6^{\text {th }}$ edition, 1422 AH / 2002 AD.

12- Awad bin Ali Al-Zahrani: Antiquities of Al-Baha Region, Riyadh, Ministry of Education - Agency for Antiquities and Museums, 1423 AH / 2003 AD.

13- Abd Allah Zaher Al-Thaqafi, Amin Younes: Islamic Civilization, Issue 1438, 12017 AD, (D. N).

14- Abd Al-Rahman Al-Tayeb Al-Ansari: Al-Baha is the smiling beauty - House of Alqwafil, 1430 AH - 2009AD, Riyadh.

15- Othman bin Abd Allah Ibn Bishr: The Title of Glory in the History of Najd, verified and commented on by: Abd Al-Rahman bin Abd Al Latif Abd Allah Al Sheikh, $4^{\text {th }}$ edition, Riyadh: King Abdulaziz House, volume 1, 1402 AH / 1982 AD.

16- Ali bin Saleh Al-Suluk: The Geographical Dictionary of the Kingdom of Saudi Arabia, Ghamid and Zahran countries, 2 ${ }^{\text {nd }}$ edition, 1401 AH-1981 AD, Dar AlYamamah, Riyadh.

17- Ghaythan bin Ali bin Gerais: Al-Baha region, studies, additions, comments, Volume 1-15 AH / q7-21AD, volume 1, $1^{\text {st }}$ edition, Al-Humaidhi Press 1440 AH / 2019 AD, Riyadh. 


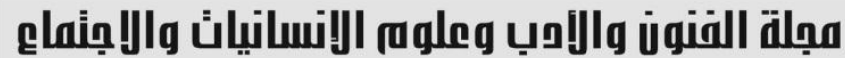 \\ Journal of Arts, Literature, Humanities and Social Sciences www.jalhss.com}

Volume (74) December 2021

العدد (74) ديسمبر 2021

18- Felix Mangan: The History of the First Saudi State and the Campaigns of Mohammed Ali Pasha on the Arabian Peninsula, translated by Mohammed Khair Mahmoud Al-Beqai, $1^{\text {st }}$ edition 1424 AH, King Abdulaziz House, Riyadh.

19- Mohammed Abd Allah bin Ahmed Al-Azraqi: History of Mecca, volume 1, Dar Al-Andalus, Beirut, 2010 AD.

20- Glimpses on the Traditional Architecture in the Asir Region - Mohammed Abd Allah Al Zulfa, $1^{\text {st }}$ edition, 1415 AH / 1995 AD.

21- Yaqout Abd Allah Al-Hamawi: Dictionary of Countries, volume 2, Dar Sader Beirut, (d.t.).

22- Ministry of Municipal and Rural Affairs, Municipal Services Series, Issue 24 / $1411 \mathrm{AH}, \mathrm{Al}$ Baha.

23- Antiquities of Al-Baha Region, Series of Antiquities of the Kingdom of Saudi Arabia, Ministry of Education, Agency for Antiquities and Museums, 1423/2003 AH, Riyadh.

24- Urban Heritage in the Kingdom of Saudi Arabia, Ministry of Municipal and Rural Affairs.

25- Urban Observatory, Al-Baha region.

26- Article about "The Saturday Market Festival" brings Baljurashi back to 400 years", Al-Madinah newspaper, Monday, 2 Jumada Al-Thani 1441 AH-January 27, 2020 AD.

27- An article entitled "Al-Atula, a village that combined the landscapes and the archaeological fortresses" Tamader Al-Wasifer - Al-Youm newspaper - Monday 8/4/2019 AD.

28- An article entitled " Rehabilitation and development stages of the heritage village of Al-Atula 3"on Saturday 6/10/2018 AD" Al-Madaen newspaper" http://www.almadaen.com.sa/273147/.

29- Article entitled "Tourism and Antiquities Restorating of the Historic Bin Raqosh Palace in Al-Baha", Sayidaty Magazine, on Sunday 25/8/2013 AD.

30- An article entitled "Barqosh Palace is an Architectural Masterpiece" by the Saudi News Agency, on Friday 28/4/1435 AH-28/2/2014 AD.

31- Raghadan People's Market "Ruins of History of Past Stories in Al-Baha", a television report by Al-Arabiya Channel, on Friday, 11 of Jumada Al-Thani, 1435 AH / April 11, 2014, at 23:00 pm. 